\title{
Habitat change in an estuarine embayment: anthropogenic influences and a regime shift in biotic interactions
}

\author{
D. Pillay ${ }^{1, *}$, G. M. Branch ${ }^{1}$, A. T. Forbes ${ }^{2}$ \\ ${ }^{1}$ Marine Biology Research Institute, Zoology Department, University of Cape Town, PB X3, Rondebosch 7701, South Africa \\ ${ }^{2}$ School of Biological and Conservation Sciences, University of KwaZulu-Natal, Durban 4041, South Africa
}

\begin{abstract}
Long term-monitoring of an intertidal sandflat in Durban Bay, South Africa, indicated a major regional transformation in macrofauna between 1994 and 2002. This sandflat, known as Little Lagoon, was composed of muddy sand in 1994, but became more sandy by 2002. This change coincided with the establishment of dense beds of the burrowing sandprawn Callianassa kraussi, and a major decline in bivalve richness and density. In 1994, bottom-feeding fish dominated the ichthyofauna, with bivalve siphons dominating their diets. In 2002, however, the fish community was dominated by zooplanktivorous fish, and bivalve siphons were absent in the stomachs of benthic fish. We hypothesised that increases in C. kraussi density between 1994 and 2002 contributed to these changes in macrofauna. To test this hypothesis, macrofauna was compared between areas of high and low C. kraussi density in Little Lagoon in 2002, to determine whether pattern differences between these areas mirrored those between 1994 and 2002. Both investigations showed that C. kraussi was negatively associated with abundances of suspension feeders, deposit feeders and surface grazers, but not with burrowing infauna abundance. Densities of bivalves in particular, were significantly reduced in areas heavily bioturbated by $C$. kraussi. These trends have since been demonstrated experimentally, and support our hypothesis that an increase in C. kraussi density contributed to these changes to macrofauna. This long-term study also highlights the 'ecosystem-engineering' role of C. kraussi, and suggests that its effects ripple through higher trophic levels by reducing the abundance of food items.
\end{abstract}

KEY WORDS: Habitat change $\cdot$ Bioturbation $\cdot$ Callianassa kraussi $\cdot$ Bivalves $\cdot$ Durban Bay

\section{INTRODUCTION}

Changes in biological interactions in marine ecosystems may profoundly alter their structure and function, often with cascading effects on other components of the ecosystem (Estes \& Duggins 1995, van Nes et al. 2007). Such shifts are usually associated with changes in the dominance of particular species. Their triggers are, however, not always immediately apparent, although climate change, anthropogenic alteration of habitats and fisheries are the causes most often invoked (Cury 2004). Dredging (Zajac \& Whitlatch 1989, De Grave \& Whitaker 1999) and bottom trawling
(Kaiser et al. 2000, 2002) for example, are known to influence benthic communities.

Here, we explore changes in macrofaunal and fish communities that have occurred in Durban Bay, an estuarine embayment on the east coast of South Africa. We present evidence for a hypothesis that these changes were at least partly driven by a shift in biological interactions over the last decade, from a bivalvedominated configuration to one in which biomass was dominated by the sandprawn Callianassa kraussi.

Durban Bay has undergone significant changes through its history. The majority of these have been anthropogenic, notably the destruction of mangrove 
swamps and intertidal sandflats (Fig. 1). Harbour developments, particularly dredging and pier construction, eliminated $90 \%$ of the original mangrove habitat and $75 \%$ of intertidal sandflats in the bay between the 1890s and 1990s. In addition, infilling and development of the bay has resulted in a loss of $57 \%$ of the original marine habitat over this period (Allan et al. 1999). Further alterations to mangroves and sandflats since 1990 have been minor, relative to the changes observed between 1890 and 1990 .

Over the last 10 to $15 \mathrm{yr}$, some areas within the remaining portions of Durban Bay have undergone major changes in physical characteristics, but the causal mechanisms driving these smaller-scale changes are less clear. Some intertidal habitats that were described as 'muddy sandflats' about a decade ago (Allan et al. 1999), have become more coarse, and are currently sandy in nature. In Little Lagoon, where our study was focused (Fig. 1), sediment particle size (mean diameter

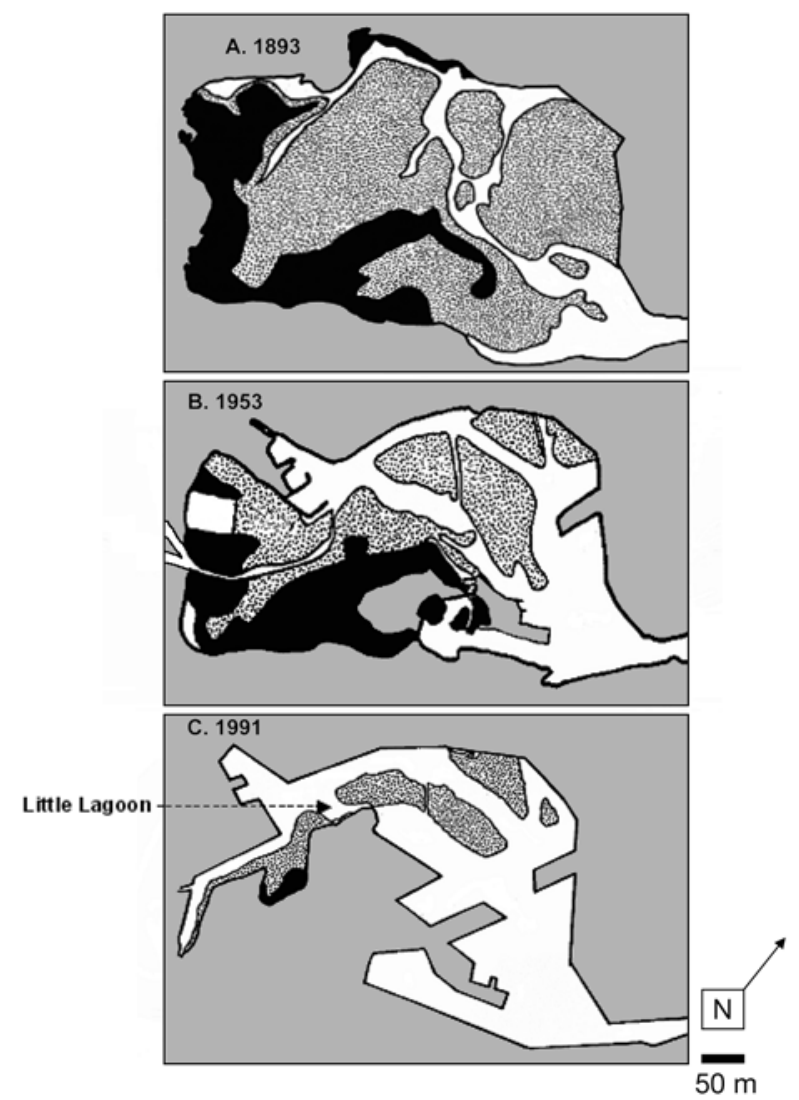

Fig. 1. Areas of intertidal sandflats (stippled) and mangroves (black) in Durban Bay in (A) 1893, (B) 1953 and (C) 1991. White areas in (A) represent channels that have been progressively widened and deepened by dredging to accommodate shipping in the harbour. Lateral encroachment reducing the size of the bay is due to landfill associated with harbour development. Adapted from Allan et al. (1999). See 'Materials and methods' for geographical coordinates of Little Lagoon $\varphi \pm \mathrm{SD})$ has significantly changed from $2.29 \pm 0.06$ in 1994 (Graham 1994) to $2.07 \pm 0.03$ in 2002 (Pillay 2002) ( $t$-test, $\mathrm{n}=12$ in 1994, $\mathrm{n}=36$ in 2002, $\mathrm{p}=0.018$ ). This alteration of sediment granulometry also coincided with changes in macrofaunal assemblages, particularly an increase in density of the burrowing sandprawn Callianassa kraussi and a decline in numbers of burrowing bivalves in Little Lagoon, as documented below.

The ecological effects of such changes in sediment composition are complex and difficult to predict. It is possible that the shift in sediment granulomentry has favoured Callianassa kraussi, which is known to occupy sandy rather than muddy areas (Day 1959). On the other hand, an increase in C. kraussi density could in itself have contributed to the alteration of sediment granulometry. Callianassid sandprawns are potent ecosystem engineers (Berkenbusch \& Rowden 2003, Siebert \& Branch 2007) and have tremendous ability to transform habitats, principally because they can achieve high densities and their turnover of sediment from burrows to the sediment surface is prodigious (Tudhope \& Scoffin 1984, Branch \& Pringle 1987, Rowden \& Jones 1993, Cadée 2001), altering sediment granulometry and composition (Suchanek 1983, Flach \& Tamaki 2001).

Bioturbation by callianassids is also a key determinant of macrofaunal community composition (Flach \& Tamaki 2001, Pillay et al. 2007a), with several studies reporting negative effects on filter-feeding bivalves. The mechanism most often invoked to explain this effect is that sediment reworking by callianassids interferes with the filtration mechanism of filter feeders, leading to reductions in growth and survival (Murphy 1985, Pillay et al. 2007a,b). It is therefore possible that any increases in Callianassa kraussi density in Durban Bay may have driven changes in other components of the biota, including diminished bivalve density. An added complexity is that bivalve siphons are known to be a key component of the diets of some benthic fish species (e.g. Tomiyama et al. 2005). Changes in benthic communities - whether directly caused by habitat alteration or as an indirect consequence of a shift to a sandprawn-dominated condition - may thus change food availability for these fish, potentially altering their local distribution and abundance.

Here, we first use data obtained from long-term monitoring studies in Little Lagoon, Durban Bay to document changes in macrofaunal communities between 1994 and 2002. Secondly, we compare the composition, abundance and diets of fish in Little Lagoon in 1994 and 2002. Thirdly, to explore whether a shift to a phase of dominance by Callianassa kraussi could have driven the macrofaunal changes, we compare areas that had high versus low densities of C. kraussi in 2002. The rationale behind this approach was that if 
patterns in macrofaunal communities evident between sites of high versus low C. kraussi densities were also apparent in comparisons between 1994 and 2002, this would provide circumstantial evidence for our hypothesis that C. kraussi mediated changes in the biota of Durban Bay. Specifically, we hypothesised that abundances of surface grazers, suspension feeders and deposit feeders would be reduced in areas where densities of C. kraussi were high, but that burrowing infauna would either be more abundant there or unaffected by the density of C. kraussi.

Finally, we draw this information together to argue that (1) Callianassa kraussi has contributed to changes in the benthos, and (2) these changes have had repercussions for the diets, composition and abundance of fish. The first part of this argument is bolstered by published experimental work on the capacity of C. kraussi to alter benthic communities (Pillay et al. 2007a,b,c, Siebert \& Branch 2007), but the second is more speculative and relies on correlative data.

\section{MATERIALS AND METHODS}

Study site. Durban Bay is situated on the east coast of KwaZulu Natal, South Africa, and is classified as an estuarine embayment. Lying within it, Little Lagoon

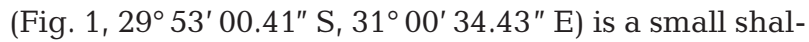
low-water bay about $100 \mathrm{~m}$ wide, with a tidal range of $\sim 1.5 \mathrm{~m}$, and flanked to the north and south by intertidal sandbanks, some areas of which are occupied by dense populations of the sandprawn Callianassa kraussi $\left(130 \pm 17.5 \mathrm{~m}^{-2}\right.$, mean $\pm \mathrm{SE}$, estimated from hole counts), whereas other areas either lack prawns or have very low densities $\left(2.7 \pm 2.5 \mathrm{~m}^{-2}\right.$, Pillay et al. 2007b,c).

Macrofaunal comparisons between 1994 and 2002. Using a Zabalocki-type Eckman grab (sampling area $236 \mathrm{~cm}^{2}$, penetration $20 \mathrm{~cm}$ ), 9 intertidal benthic samples were collected from random positions in Little Lagoon on each of 4 sampling 'seasons' at 3 mo intervals in 1994 (Graham 1994). In 2002, 6 intertidal sites were sampled: 9 grab samples were taken per site during each of 6 'seasonal' 3-monthly sampling sessions (Pillay 2002). The samples were passed through a $0.5 \mathrm{~mm}$ sieve to separate the macrofauna, which was preserved in $4 \%$ formalin and stained with Phloxine-B. Apart from the level of replication, sampling methods conducted in the 1994 and 2002 studies were identical.

Fish sampling in 1994 and 2002. In 1994, fish were sampled on 4 occasions at 4 mo intervals using a $70 \times$ $2 \mathrm{~m}$ seine net with a $25 \mathrm{~mm}$ mesh size $(13 \mathrm{~mm}$ in the purse). Replicates of 4, 2, 3 and 3 seines were collected in the respective sampling seasons (Graham 1994). In 2002, a $30 \times 2 \mathrm{~m}$ seine net with a mesh of $27 \mathrm{~mm}$
(10 $\mathrm{mm}$ in the purse) was used, and 6 sampling sessions were conducted at 3 mo intervals. Replicates consisted of $4,3,8,3,3$ and 4 samples in the respective sessions (Blackler 2002). In both 1994 and 2002, guts were dissected from the fish and the frequency of occurrence of stomach constituents scored.

Macrofaunal comparisons of areas with high and low densities of Callianassa kraussi. Samples were taken in Little Lagoon in 2001-2002 to compare macrofauna in areas with high and low densities of Callianassa kraussi. The unequal sizes of the high- and lowdensity patches dictated an unbalanced sampling design, with 4 sites sampled in areas of high C. kraussi density (H1-H4) and two in areas of low density (L1 and L2, see Pillay et al. 2007c). In both areas, the abundance of C. kraussi was measured from hole counts and samples of macrofauna collected in March, June, September and December 2001, and March and June of 2002. Two methods were used to sample macrobenthic communities: (1) a Zabalocki-type Eckman grab identical to that used in 1994, and (2) a stainless-steel prawn pump (diameter $5 \mathrm{~cm}$, sampling area $19.6 \mathrm{~cm}^{2}$, penetration $90 \mathrm{~cm}$ ). In total, 9 grab and 15 core samples were collected per sampling site on each sampling occasion.

Physical factors. Water temperature, salinity and dissolved oxygen were measured at each site on each sampling occasion in 2001-2002, using a portable Horiba U-10 water sampler. Measurements were taken approximately $10 \mathrm{~cm}$ above the sediment surface at midshore level during spring high tides. Sediment samples were collected from the upper 5 to $10 \mathrm{~cm}$ of the sediment, and median particle sizes and organic content determined according to methods described by Morgans (1956).

Statistical analyses. All multivariate analyses were performed using PRIMER v. 5 (Plymouth Routines in Multivariate Ecological Research, Clarke \& Warwick 1994). Cluster analysis and non-metric multidimensional scaling (MDS) were used to assess differences in macrofaunal assemblages between 1994 and 2002 and between areas of high and low Callianassa kraussi densities. ANOSIM was employed to test if assemblages differed statistically among treatments. Dendrograms and MDS ordinations were constructed from similarity matrices generated from Bray-Curtis similarities, with untransformed and unstandardised abundance data. For each treatment, the DIVERSE procedure was used to calculate total abundance $(\mathrm{N})$, species richness expressed as total number of species per sample (S), and Shannon-Wiener diversity $\left(H^{\prime}\right)$ to the base e. SIMPER was used to determine the significance of differences in abundances of taxa among treatments. Differences in macrofaunal community parameters among treatments were determined using 1-way ANOVAs separately for each sampling season. 
Normality and homogeneity of variance required for parametric testing were assessed using the Kolmogorov-Smirnov and Levene's tests, respectively. In instances where these assumptions were not met, data were transformed $(\log [x+1]$ or arcsin). In cases where the abundance of a given species was zero for all samples in one treatment, no statistical tests were run because the absence of variance precluded valid statistical comparisons.

\section{RESULTS}

\section{Differences in macrofaunal communities between 1994 and 2002}

Cluster analysis indicated that macrofaunal communities in Little Lagoon had undergone a major change between 1994 and 2002 (Fig. 2, ANOSIM, p = 0.005). The dissimilarity in macrofaunal assemblages between 1994 and 2002 was largely due to the reductions in density of bivalve species over this period (Fig. 3). Of the 7 species that declined significantly in abundance between 1994 and 2002, 5 were bivalves (Dosinia hepatica, Eumarcia paupercula, Brachidontes virgiliae, Tellina prismatica and Solen cylindraceus), with the remaining 2 being a surface-grazing gastropod (Nassarius kraussianus) and a deposit-feeding polychaete (Prionospio sexoculata). In addition, 2 surface-dwelling gastropods (Assiminea ovata and Finella natalensis) were present in 1994 but not recorded in 2002. No species increased significantly between 1994 and 2002, but 2 burrowing species that were initially absent appeared in 2002, i.e. Callianassa kraussi and Scoloplos johnstonei. In 2002, mean densities of $16 \mathrm{~m}^{-2}( \pm 9, \mathrm{SD})$ were recorded for $C$. kraussi using the grab. This is a significant underestimate of C. kraussi densities due to the shallow depth sampled by the grab. A more realistic measure of densities comes from values obtained using a prawn pump, in which the density averaged $66 \mathrm{~m}^{-2}$ $( \pm 46.2, \mathrm{SD})$. When the clusters of 1994 and 2002 samples detected in the MDS analysis were analysed as proportions of specific functional groups of macrofauna, drastic changes were evident between the 2 periods, with densities of suspension feeders (E. paupercula, B. virgiliae, T. prismatica), surface grazers (N. kraussianus and A. ovata) and deposit feeders (Dosinia hepatica) being significantly greater in 1994 than in 2002. However, the numbers of the burrowing infaunal

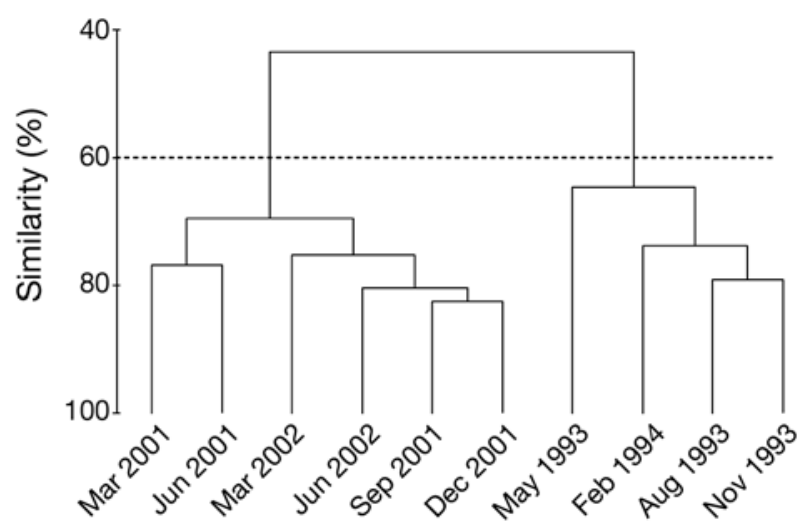

Fig. 2. Dendrogram showing differences in macrofaunal assemblages in Little Lagoon between 1994 (4 seasons of sampling) and 2002 (6 seasons of sampling) at the $60 \%$ level of similarity (indicated by dotted line)

species Scoloplos johnstonei and Glycera sp. were not significantly different between the 2 periods (Fig. 4).

\section{Differences in fish fauna between 1992 and 2002}

The composition of fish assemblages also changed between 1994 and 2002 (Fig. 5). In 1994, the benthic invertebrate-eaters Pomadasys commersonni, Gerres filamentosus, Leiognathus equula and the benthic detritivore Liza dumerilli were the 4 most dominant fish species, cumulatively accounting for more than $85 \%$ of the assemblage in Little Lagoon, but by 2002 their contri-

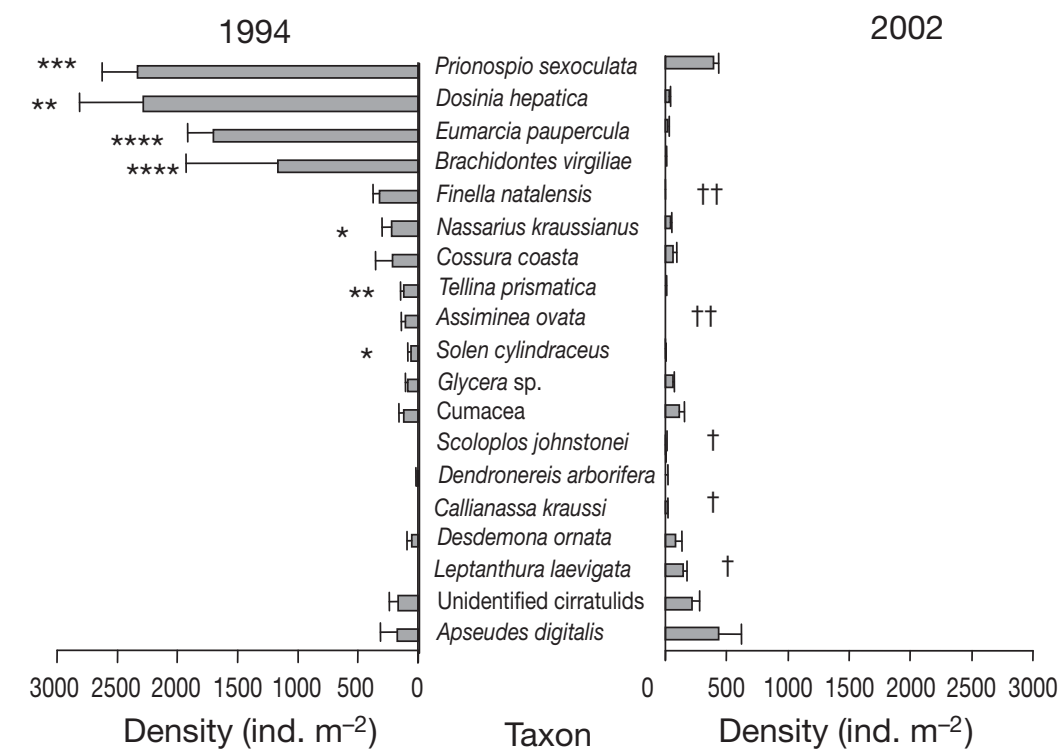

Fig. 3. Changes in mean densities + SE of macrobenthic taxa between 1994 and 2002, based on data pooled across seasons. Data for 1994 derived from Graham (1994), 2002 data from Pillay (2002); $t$-tests, ${ }^{\star * \star *} \mathrm{p}<0.0001,{ }^{* \star *} \mathrm{p}<0.001,{ }^{\star *} \mathrm{p}<$ $0.01,{ }^{*} \mathrm{p}<0.05 ; \dagger+$ : decrease in density to 0 ; †: increase in density from 0 


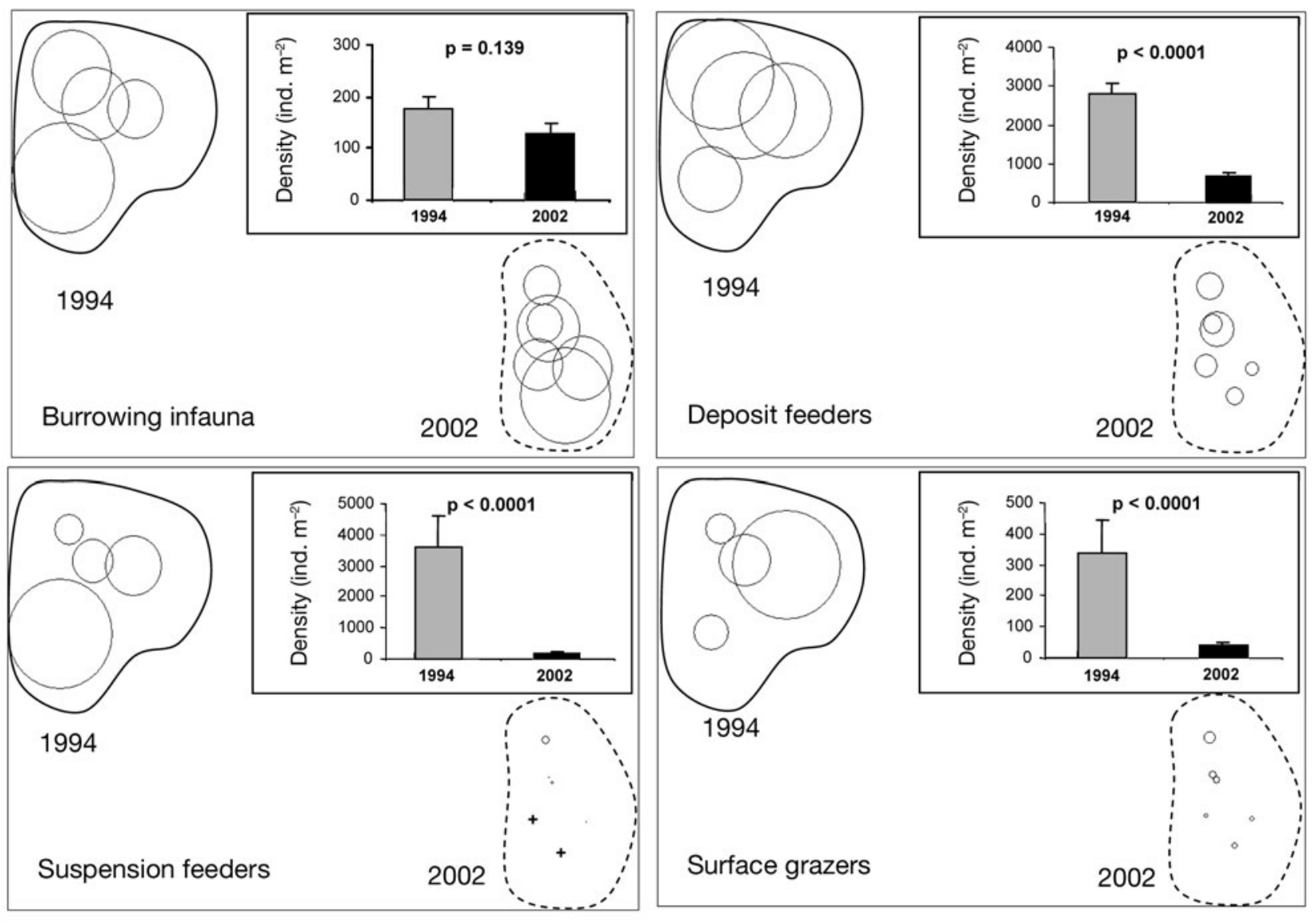

Fig. 4. MDS ordination plots showing the division of 1994 and 2002 samples into 2 discrete clusters distinguished at $40 \%$ dissimilarity, with differences in densities of functional groups between 2002 and 1994 overlain as circles on the positions of the individual samples in the MDS plots. Each data point represents a sampling season, with replicate samples pooled by season. Circle diameters are proportional to the densities of organisms within each functional group, with the largest circle representing $6500 \mathrm{~m}^{-2} ;+$ denotes a zero recording. Stress $=0.1$ for all ordinations. Insets: Differences in densities (means $+\mathrm{SE}$ ) of organisms belonging to each functional group between 1994 (grey bars) and 2002 (black bars)

bution had declined to $17 \%$. Conversely, the planktivorous genus Ambassis was dominant in 2002 when it comprised $80 \%$ of the assemblage, up from $2.1 \%$ in 1994 . These patterns were consistent across all sampling seasons. In 1994, bivalve siphons made important contributions to the diets of the 3 dominant benthic invertebrate- eating fish species in Little Lagoon, contributing $6 \%, 15$ and $22 \%$ to the diets of $G$. filamentosus, $L$. equula and $P$. commersonnii, respectively. In 2002, bivalve siphons were never recorded in the guts of the 3 benthic invertebrate feeders encountered, i.e. G. filamentosus, L. equula and Sillago sihama (Fig. 6).

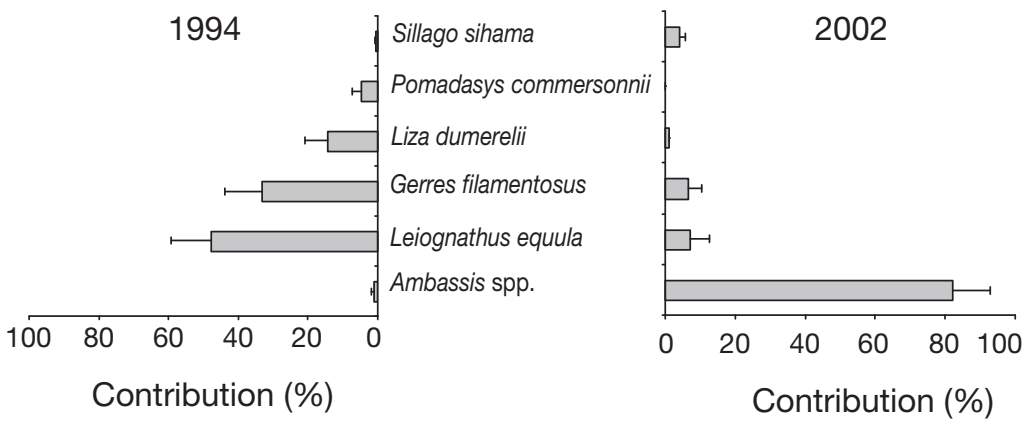

Fig. 5. Percentage contributions (means $+\mathrm{SE}$ ) of the most dominant fish (collectively constituting $>90 \%$ of the catch in Little Lagoon) in 1994 and 2002. Data pool is replicated within seasons

\section{Differences in macrofauna between sites of high and low Callianassa kraussi density}

In 2002, Callianassa kraussi was consistently and significantly more abundant in the areas of Little Lagoon designated 'high density C. kraussi areas' than 'low density C. kraussi areas' (Fig. 7, $t$-test, $\mathrm{p}<0.05$ for all sampling seasons), quantitatively confirming these prior designations. 


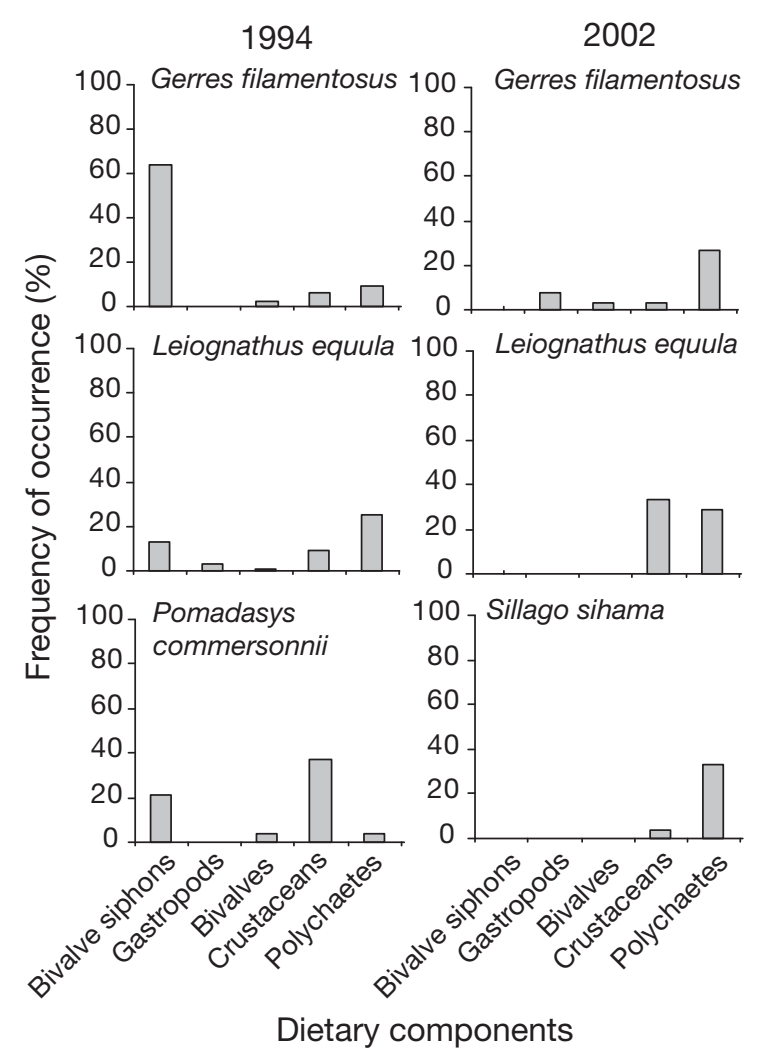

Fig. 6. Diets of the 3 most dominant benthic fish species in Little Lagoon in 1994 and 2002, respectively

Ordination plots indicated that macrobenthic communities were significantly different between areas of high and low Callianassa kraussi abundance (Fig. 8, ANOSIM, $\mathrm{p}<0.001$ for both grab and core data). Total abundance, species richness and diversity of macrofauna obtained from core samples (Fig. 9A) were significantly greater in low-density than in high-density areas ( $t$-tests, $\mathrm{p}<0.0001$ for all measures). In the case of grab samples (Fig. 9B), total abundance and species richness were again significantly greater in sites of low C. kraussi density ( $\mathrm{p}<0.0001$ and $\mathrm{p}<0.01$, respectively), but diversity was not ( $p=0.59)$.

Multivariate and univariate analyses showed that the composition of macrofaunal communities differed between sites of high and low Callianassa kraussi densities. Fig. 10 summarises the differences and indicates those species that differed significantly in univariate analyses or were identified by SIMPER as contributing to the top $70 \%$ of dissimilarity between the 2 periods. Three patterns emerged. First, it was largely the same group of taxa that defined the differences between areas of high and low C. kraussi abundance in both grab and core samples. Second - and most obviously in core samples - burrowing taxa were more abundant in areas of high C. kraussi abundance whereas shallow-dwelling grazers, deposit- and suspension-

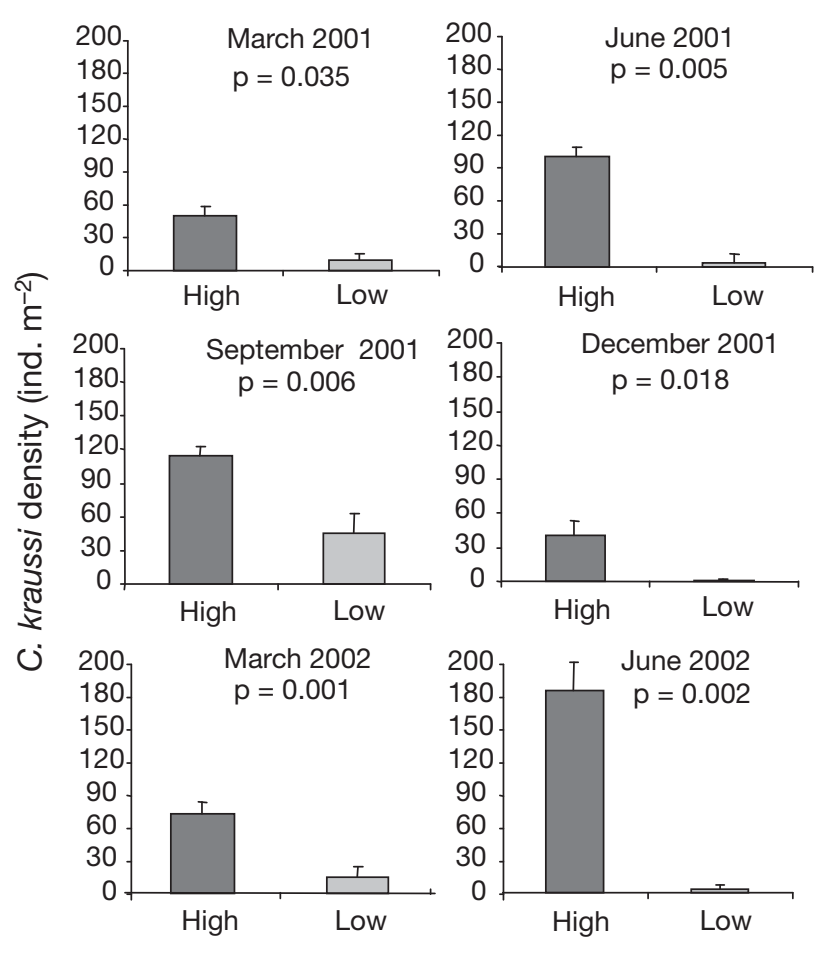

Fig. 7. Differences in Callianassa kraussi densities (means + $\mathrm{SE}$ ) between patches of high and low C. kraussi abundance in Little Lagoon in 2001-2002 as determined from hole counts. $t$-tests for significant differences

feeders were all more abundant in areas with low C. kraussi densities. Third, the top 6 species that were more abundant in 1994 than 2002 and contributed most to the differences between these periods (Fig. 3) were all either more abundant in areas of low C. kraussi densities, or had declined to the extent that comparisons were impossible.

Data from grab and cores samples indicated that deposit feeders, suspension feeders and surface grazers were negatively affected by Callianassa kraussi bioturbation activity (Fig. 11), with their densities being significantly greater in sediments that were not bioturbated by C. kraussi (Fig. 11 ; $t$-tests, p $<0.001$ in all cases). Burrowing species were not affected by C. kraussi, i.e. densities did not differ significantly between areas of high and low C. kraussi densities (Fig. 11).

\section{Physical factors in areas of high and low densities of Callianassa kraussi}

Water temperature, salinity, dissolved oxygen, sediment particle size and organic content were never significantly different between sites of high and low Callianassa kraussi densities ( $t$-tests, p > 0.1) in any of the seasons examined (Table 1). 

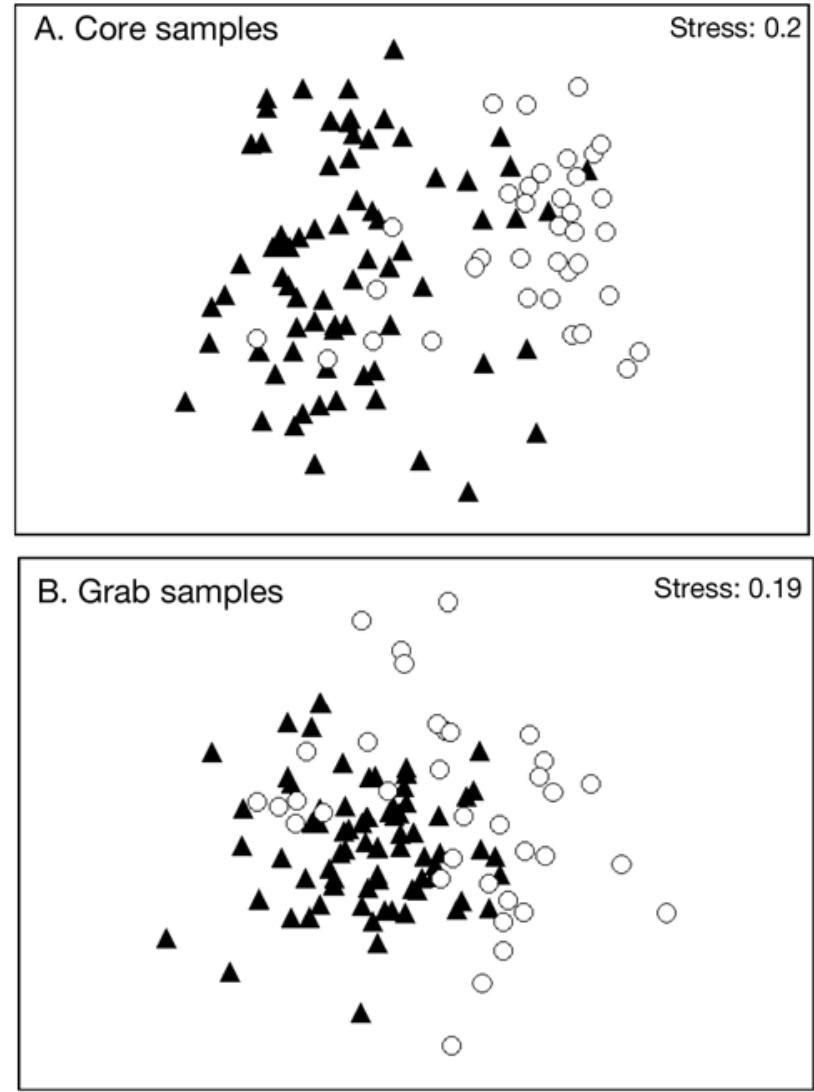

O Low C. kraussi $\Delta$ High C. kraussi

Fig. 8. MDS ordinations showing differences in macrofaunal assemblages betweeen sites of high and low Callianassa kraussi abundance based on data obtained in 2002 from (A) core and (B) grab samples. Differences between high- and low-density areas were significant in both cases $(p=0.001$, ANOSIM)

\section{DISCUSSION}

Our aim was to document biotic changes that have occurred in Durban Bay over the last decade, and to evaluate anthropogenic effects and the role of a shift in biotic interactions as drivers of these changes, as summarized in Fig. 12. Many of these changes have been anthropogenically induced, but our results provide evidence supportive of the hypothesis that alterations to fish and macrofaunal communities in Little Lagoon over the last decade were, at least in part, driven by the establishment of dense populations of Callianassa kraussi (Fig. 12).

To test this hypothesis, we gathered data to compare (1) macrofaunal and (2) fish communities between 1994, when Callianassa kraussi was absent, and 2002, when it had become established at a range of densities, and (3) the macrofauna associated with areas of high
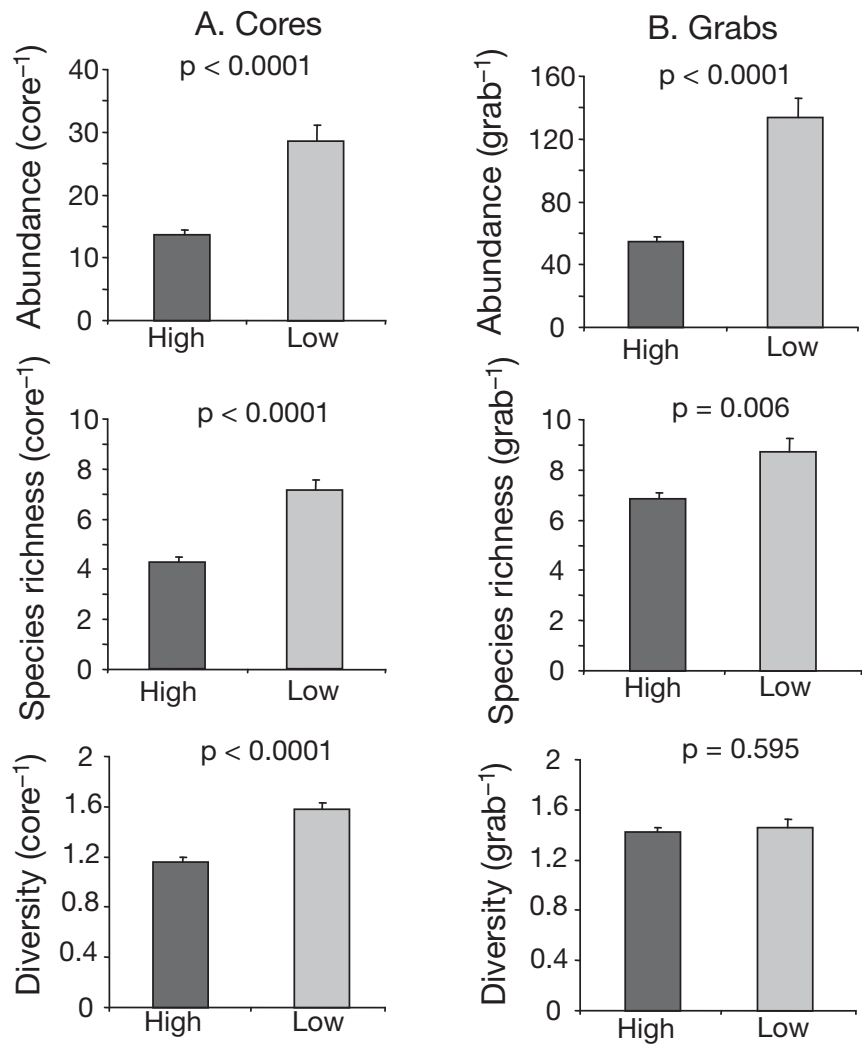

Fig. 9. Differences in abundance, species richness and diversity (Shannon-Wiener diversity $H^{\prime}$ to the base e) of macrofauna between regions of high (dark grey bars) and low densities of Callianassa kraussi (light grey bars) based on (A) core and (B) grab samples. Means + SE. Core samples were from areas of $19.5 \mathrm{~cm}^{-2}$, and grab samples from areas of $236 \mathrm{~cm}^{-2} \cdot \mathrm{p}$-values are for $t$-tests

and low densities of C. kraussi in 2002. All these comparisons relied on a 'natural experiment' approach (Clarke \& Warwick 1994), which cannot provide conclusive evidence of cause-and-effect relationships because there is no control over environmental conditions, so results can potentially be confounded by differences that are not related to the factors being considered. We partially countered this criticism by measuring environmental conditions in our study of macrofaunal assemblages between areas of high and low C. kraussi density, and detected no significant differences in physico-chemical variables between sites of high and low C. kraussi densities (Table 1), reinforcing the notion that $C$. kraussi density was the most likely determinant of benthic community structure in Little Lagoon, not differences in physical conditions.

The advantages of the natural experiment approach are that results obtained reflect realistic field conditions and are not influenced by experimental artefacts, as they may be when field manipulative experiments are undertaken (Berkenbusch et al. 2000). This 


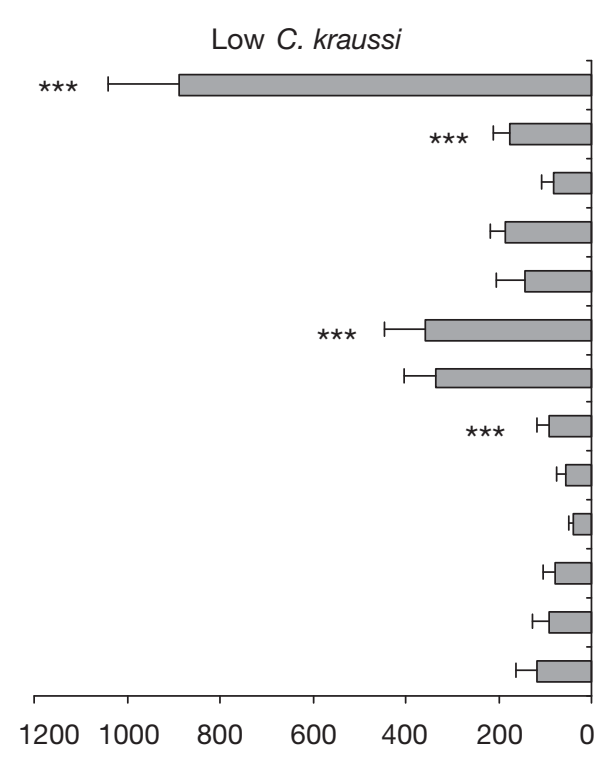

\section{Core samples}

Prionospio sexoculata ${ }^{a}$

Leptanthura laevigata ${ }^{a}$

Desdemona ornata

Cumacea $^{a}$

Apseudes digitalis

Dendronereis arborifera

Cirratulids $^{\mathrm{a}}$

Eumarcia paupercula ${ }^{a}$

Dosinia hepatica

Nassarius kraussianus

Glycera sp. ${ }^{a}$

Unidentified amphipoda

Scoloplos johnstone ${ }^{\mathrm{a}}$

\section{Grab samples}

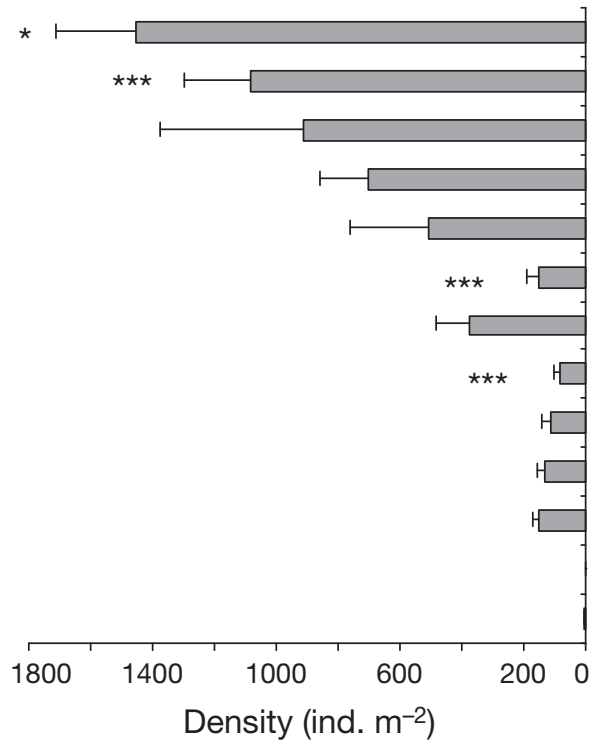

Prionospio sexoculata ${ }^{a}$

Leptanthura laevigata ${ }^{a}$

Desdemona ornata ${ }^{a}$

Cumacea $^{a}$

Apseudes digitalis ${ }^{\mathrm{a}}$

Dendronereis arborifera

Cirratulids $^{a}$

Eumarcia paupercula ${ }^{a}$

Dosinia hepatica ${ }^{a}$

Nassarius kraussianus ${ }^{a}$

Glycera sp. $^{\text {a }}$

Unidentified amphipod

Scoloplos johnstonei

Taxon
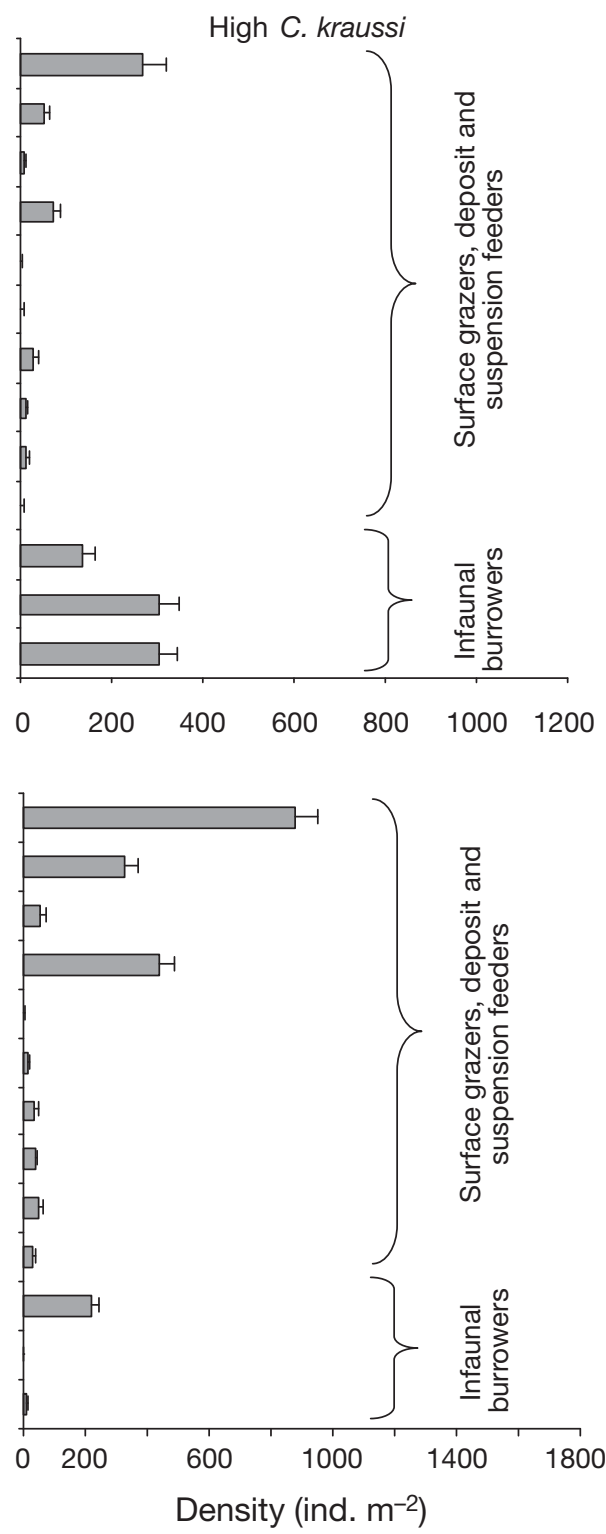

Fig. 10. Differences in mean (+SE) densities of macrobenthic organisms between regions of high and low Callianassa kraussi density based on core and grab samples. Asterisks indicate significant differences between densities: $t$-tests, ${ }^{*} \mathrm{p}<0.05$, ${ }^{* * \star} \mathrm{p}<$

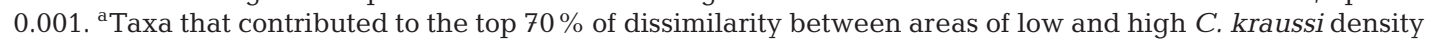

approach can be especially conclusive with replication from sites with contrasting levels of the factor being investigated. In addition, natural experiments form a foundation for experimental work, and provides the context for interpretation of experimental work (Underwood et al. 2000).

Our observational data showed that macrofaunal community structure differed significantly between sites of high and low Callianassa kraussi density. Abundance and richness of macrofauna were statistically greater in sites of low C. kraussi densities. Certain functional groups of macrofauna were particularly susceptible to bioturbation by C. kraussi, with densities of suspension feeders, surface grazers and deposit feeders being significantly reduced in areas where C. kraussi was abundant, whereas burrowing infauna was unaffected by C. kraussi bioturbation. Almost exactly comparable patterns emerged from field experiments in which the presence of C. kraussi was controlled by using inclusion/exclusion cages (Pillay et al. 2007a), increasing confidence that these differences were attributable to the effects of $C$. kraussi. In addition, the same patterns were also recorded when comparing macrofauna in Little Lagoon between 1994 

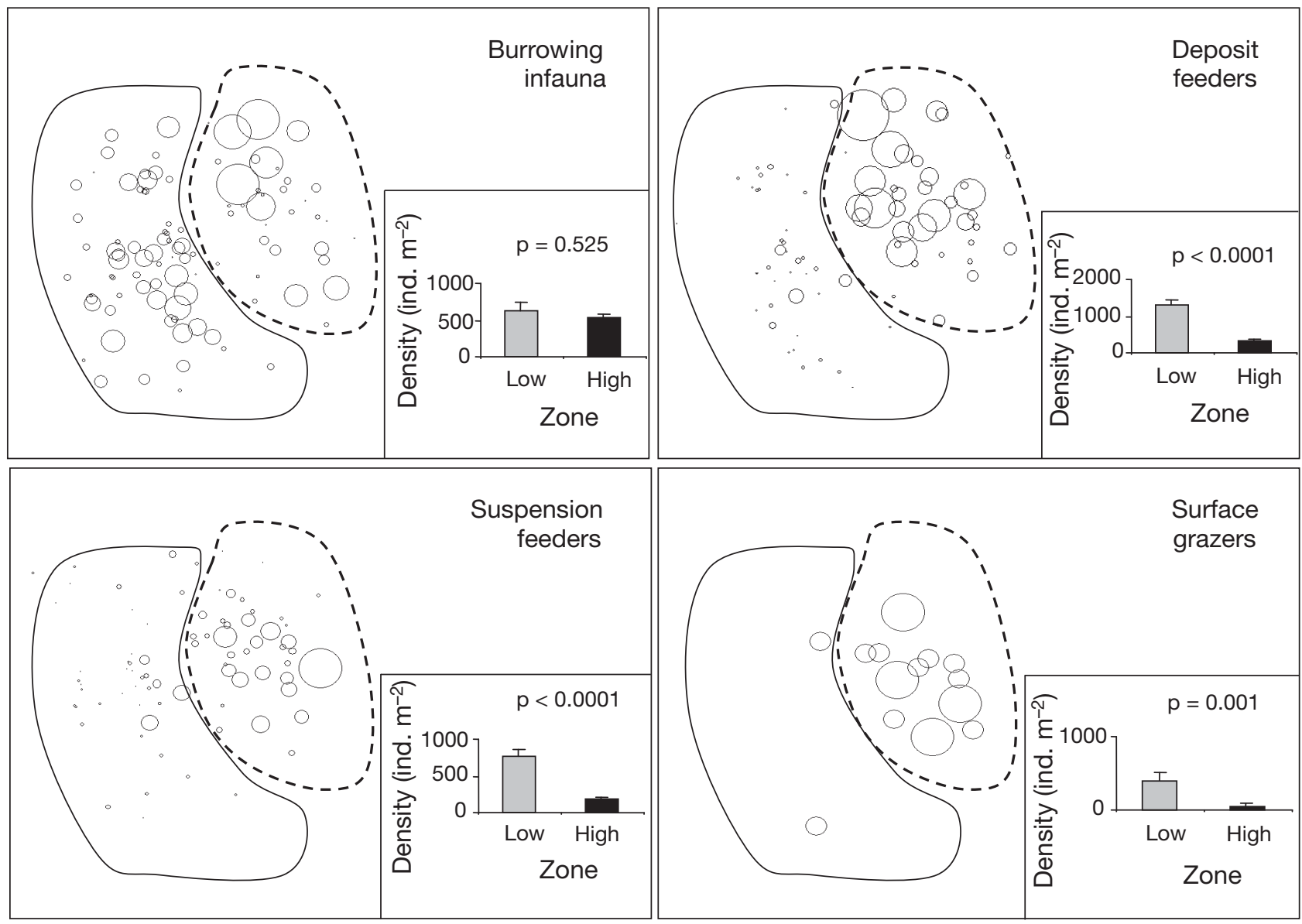

Fig. 11. MDS ordination plots showing differences in densities of functional groups between 2 clusters distinguishable for areas with low-densities (enclosed by a solid line) and high-densities of Callianassa kraussi (enclosed by a dashed line). Data are based on core samples pooled across all sampling seasons. Circle diameters are proportional to the densities of organisms within each functional group. Stress $=0.2$ for all ordinations. Insets: differences in densities (means $+\mathrm{SE}$ ) of organisms belonging to each functional group at sites of low densities (grey bars) and high densities (black bars) of C. kraussi.

Table 1. Physico-chemical variables in sites of high and low Callianassa kraussi density. Values are means $\pm \mathrm{SE}$

\begin{tabular}{|lllcccrr|}
\hline Year & Season & Zone & $\begin{array}{c}\text { Temperature } \\
\left({ }^{\circ} \mathrm{C}\right)\end{array}$ & $\begin{array}{c}\text { Salinity } \\
(\%)\end{array}$ & $\begin{array}{c}\text { Dissolved } \\
\text { oxygen }\left(\mathrm{mg} \mathrm{l}^{-1}\right)\end{array}$ & $\begin{array}{c}\text { Sediment organic } \\
\text { content }(\%)\end{array}$ & $\begin{array}{c}\text { Sediment median } \\
\text { particle size }(\varphi)\end{array}$ \\
\hline 2001 & March & High & $27.13 \pm 0.66$ & $29.48 \pm 0.28$ & $6.22 \pm 0.79$ & $2.78 \pm 0.90$ & $2.33 \pm 0.15$ \\
& & Low & $28.85 \pm 0.64$ & $28.00 \pm 0.00$ & $6.54 \pm 0.00$ & $2.49 \pm 1.24$ & $2.00 \pm 0.14$ \\
& June & High & $22.43 \pm 0.30$ & $34.78 \pm 0.60$ & $5.87 \pm 0.38$ & $2.54 \pm 0.62$ & $2.11 \pm 0.20$ \\
& & Low & $23.00 \pm 0.00$ & $35.15 \pm 0.21$ & $7.84 \pm 1.22$ & $2.65 \pm 1.41$ & $2.00 \pm 0.14$ \\
& September & High & $21.75 \pm 0.86$ & $37.13 \pm 0.17$ & $6.96 \pm 0.22$ & $2.42 \pm 0.57$ & $2.08 \pm 0.14$ \\
& December & Low & $21.45 \pm 0.49$ & $35.65 \pm 2.05$ & $6.69 \pm 0.29$ & $2.72 \pm 1.17$ & $1.95 \pm 0.07$ \\
& & High & $26.23 \pm 0.50$ & $28.30 \pm 1.40$ & $6.92 \pm 0.54$ & $2.62 \pm 0.87$ & $2.10 \pm 0.18$ \\
2002 & Low & $25.35 \pm 0.10$ & $32.8 \pm 0.49$ & $7.01 \pm 0.07$ & $2.91 \pm 0.17$ & $1.9 \pm 0.00$ \\
& \multirow{2}{*}{ March } & High & $25.35 \pm 0.21$ & $32.80 \pm 0.99$ & $7.01 \pm 0.14$ & $2.91 \pm 0.35$ & $1.90 \pm 0.00$ \\
& June & Low & $26.88 \pm 0.69$ & $33.80 \pm 3.07$ & $5.50 \pm 0.49$ & $3.19 \pm 0.89$ & $1.95 \pm 0.19$ \\
& High & $28.40 \pm 0.28$ & $36.05 \pm 0.07$ & $6.86 \pm 0.17$ & $3.05 \pm 1.29$ & $2.15 \pm 0.07$ \\
& Low & $28.43 \pm 0.62$ & $30.58 \pm 0.72$ & $7.85 \pm 0.44$ & $3.07 \pm 0.82$ & $2.03 \pm 0.21$ \\
\hline
\end{tabular}

when C. kraussi was absent, and 2002 when it had become established. Taken collectively, these lines of evidence provide strong evidence that changes in macrofauna over this period were driven by C. kraussi.
The observation that suspension feeders, particularly bivalves, surface grazers and deposit feeders favoured the zone where Callianassa kraussi was rare indicates that C. kraussi likely suppresses these 


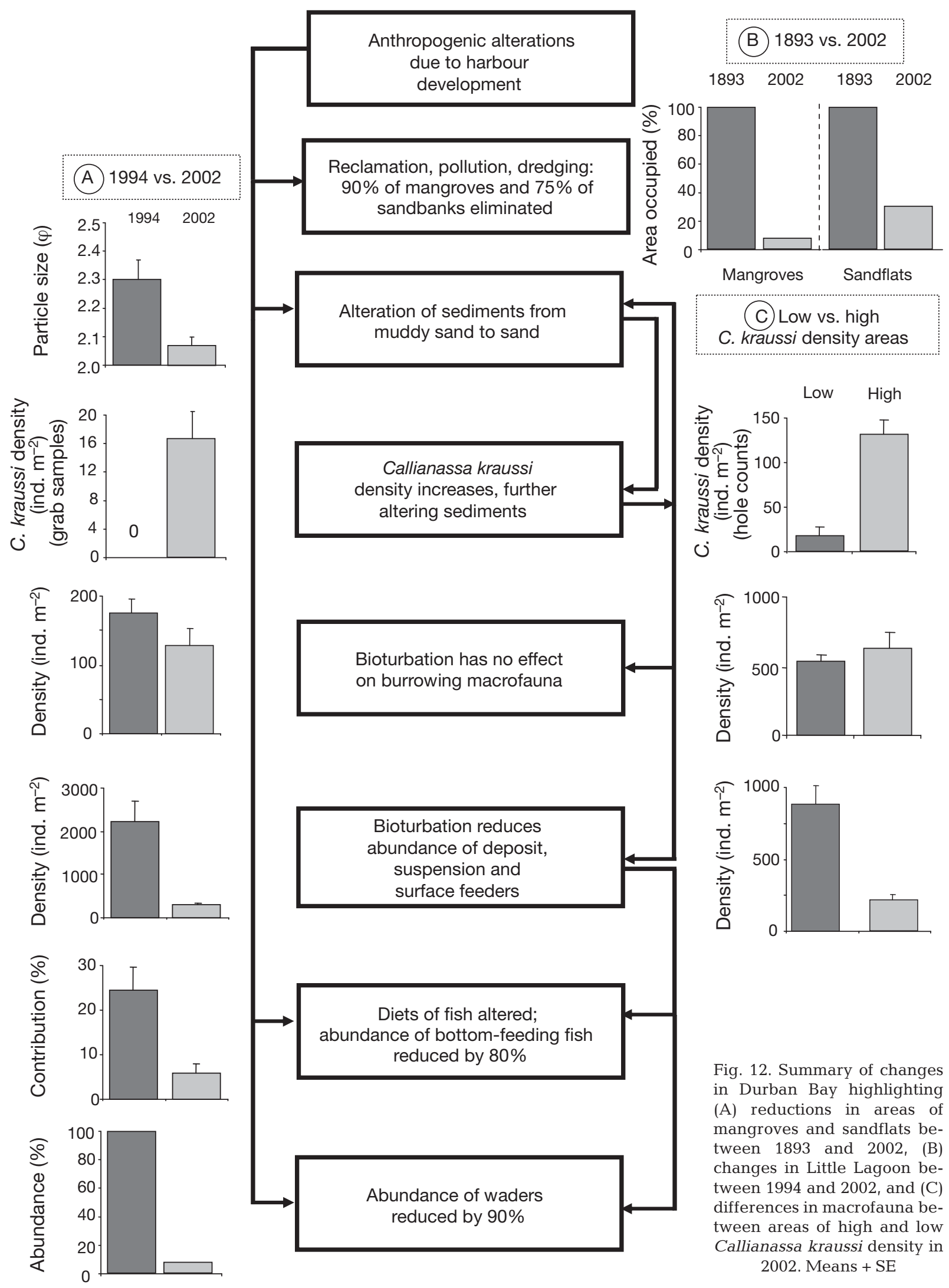


groups, probably by hindering feeding activities, destroying tubes they build, or burying these organisms. Bivalves may be 'excluded' because their siphons are clogged by sediments expelled from burrows of C. kraussi, leading to a reduction in their filtration rates (Rhoads \& Young 1970, Ellis et al. 2002). In Langebaan Lagoon on the west coast of South Africa, where C. kraussi reaches densities of $\sim 200 \mathrm{~m}^{-2}$, bivalves are also rare (Siebert \& Branch 2005a,b).

Further experiments have shown that Callianassa kraussi negatively affects microalgal consumption by Eumarcia paupercula and Nassarius kraussianus, as well as the survival and condition of E. paupercula (Pillay et al. 2007b), the latter effects being directly related to an increase in sediment erodability induced by C. kraussi. In a separate investigation, we showed that C. kraussi negatively affects recruitment of bivalves (Pillay et al. 2007a), leading to the hypothesis that larvae of suspension-feeding bivalves preferentially reject sediments inhabited by $C$. kraussi in favour of those where C. kraussi is rare, thereby increasing their survival and feeding opportunities (Pillay et al. 2007a). Both mechanisms would explain the observed trend of reductions in adult bivalves at times or in sites with abundant $C$. kraussi, reinforcing the idea that C. kraussi was the driving mechanism behind the decline in bivalve density in Little Lagoon between 1994 and 2002.

Changes in soft bottom communities in response to a shift to a callianassid-dominated state have also been recorded in the Ariake Sound System in Japan, where a 10-fold increase in densities of the callianassid sandprawn Nihonotrypaea harmandi between 1979 and 1998 was accompanied by local extinction of the grazing gastropod Umbonium moniliferum, which dropped from densities of $2000 \mathrm{~m}^{-2}$ in 1979 to zero in 1986 (Tamaki 1994). Following a decline in densities of N. harmandi in 1995, U. moniliferum staged a recovery (Flach \& Tamaki 2001). In addition, densities of the tube-building polychaete Pseudopolydora paucibranchiata, which was the most dominant macrobenthic species prior to 1979 , were reduced substantially following the build up of $N$. harmandii, as were densities of the surface deposit-feeding opheliid polychaete Armandia amakusaensis. In all cases, the sediment destabilising effect of bioturbation by $N$. harmandi was identified as the mechanism driving such community changes (Flach \& Tamaki 2001).

Van Nes et al. (2007) reported similar changes in the North Sea benthos, also associated with a shift in biotic interactions to a sandprawn-dominated state. The brittle-star Amphiura filiformis was the dominant benthic macrofaunal species between 1984 and 1992 in the North Sea, with densities between 1433 and $1750 \mathrm{~m}^{-2}$. After 1992, it declined to $<10 \%$ of initial density, coinci- dent with an increase in abundance of the burrowing shrimp Callianassa subterranea from roughly $50 \mathrm{~m}^{-2}$ in 1982 to $200 \mathrm{~m}^{-2}$ in 1992. The highly erodable sediments occupied by $C$. subterranea may have hampered recruitment of juvenile $A$. filiformis, and is the likely mechanism responsible for the decline in A. filiformis.

Collectively, these investigations provide strong evidence for our hypothesis that macrofaunal changes in Little Lagoon, specifically the decline in bivalve densities in the bay over the last decade, may have been driven by the bioturbative activities of Callianassa kraussi. Because of the negative effect of C. kraussi on bivalves, we believe that $C$. kraussi may have also played a role in structuring fish communities in Little Lagoon by affecting their food items. When bivalves were abundant in Little Lagoon, bivalve siphon tips constituted a major food source for benthic fish, viz. grunter Pomadasys commersonnii, slimy Leiognathus equula and the pursemouth Gerres filamentosus. Eight years later, the relative abundances of these species had dropped, while those of zooplanktivorous Ambassis spp. increased by 2 orders of magnitude. Importantly, at that time bivalve siphons were absent from the gut contents of all the benthic-feeding fish species, which were then feeding primarily on polychaetes and copepods.

Historically, Little Lagoon played a key role as habitat for wading birds feeding on benthic invertebrates, but there has been an almost a 10-fold decline in their abundance in Little Lagoon over the last 20 yr (Allan et al. 1999, McInnes et al. 2005). Anthropogenic disturbances and changes are likely the main reason for this decline. However, reductions in bivalve and gastropod density driven by increases in Callianassa kraussi abundance may additionally have reduced the suitability of Little Lagoon as a feeding habitat for waders.

We believe there is strong evidence that increases in the abundance of Callianassa kraussi over the period 1994-2002 played a dominant role in shaping the composition of the benthic macrofauna. Temporal changes in the benthos, differences between sites with high and low densities of C. kraussi and experimental manipulations all point to this conclusion. Anthropogenic influences such as pollution, dredging and fishing would of course contribute to the alteration of the benthos. Indeed, it is likely that dredging and reclamation caused the shift in sediment composition from muddy to sandy sediments, which may in turn have been the initial spur favouring an increase in C. kraussi.

Alteration of the benthos by an increase in Callianassa kraussi appears to have had cascading effects on other components of the system, with apparent consequential changes in fish diet and abundance, and the numbers of waders, although the evidence for these links remains circumstantial. 
The cascading effects of Callianassa kraussi on Little Lagoon are similar to the hypothesised effects of sea otters Enhydra lutris on kelp forests in the Northwest Pacific, where predation by sea otters on sea urchins has indirectly favoured the development of kelp forests by reducing grazing pressure on kelp (Estes et al. 1978). However, subsequent increased predation by killer whales on sea otters has been hypothesised to have significantly transformed this ecosystem, by freeing urchins of predation pressure (Estes et al. 1998).

For some of the links in this cascade, the absence of evidence from direct experimentation makes it impossible to be certain about the causal links, but the observational data are persuasive. In our case, the effects of Callianassa kraussi on adult assemblages, juvenile recruitment and condition and feeding of adult components of the infauna have been demonstrated experimentally (Pillay et al. 2007a,b,c); but the links to fish and birds remains tentative. Collectively, studies have shown that C. kraussi plays a pivotal role in soft-sediment ecosystems, affecting bacteria, microalgae, and meiofauna (Branch \& Pringle 1987), and the composition and abundance of benthic macrofauna (Pillay et al. 2007a,b,c). This study, however, indicates that the sphere of influence of callianassids as 'ecosystem engineers' may extend further to potentially encompass all trophic levels.

\section{LITERATURE CITED}

Allan DG, Sinclair JC, Rossouw J (1999) The waterbirds (Aves) of Durban Bay: current status and historical trends. Durban Mus Novitates 24:1-21

Berkenbusch K, Rowden AA (2003) Ecosystem engineering moving away from 'just-so' stories. N Z J Ecol 27:67-73

Berkenbusch K, Rowden AA, Probert PK (2000) Temporal and spatial variation in macrofauna community composition imposed by ghost shrimp Callianassa filholi bioturbation. Mar Ecol Prog Ser 192:249-257

Blackler JM (2002) The ichthyofaunal sssemblage of the Little Lagoon (Durban Bay: KwaZulu Natal) with emphasis on the feeding ecology of three demersal fish species. MSc thesis, University of KwaZulu, Durban

Branch GM, Pringle A (1987) The impact of the sand prawn Callianassa kraussi Stebbing on sediment turnover and on bacteria, meiofauna, and benthic microflora. J Exp Mar Biol Ecol 107:219-235

Cadée GC (2001) Sediment dynamics by bioturbating organisms. In: Reise K (ed) Ecological comparisons of sedimentary shores. Ecological studies, Vol 151. Springer-Verlag, Berlin, p 127-148

Clarke KR, Warwick RM (1994) Change in marine communities: an approach to statistical analysis and interpretation. Natural Environmental Research Council, Plymouth

Cury PM (2004) Tuning the ecoscope for the ecosystem approach to fisheries. Mar Ecol Prog Ser 274:272-275

Day JH (1959) The biology of Langebaan Lagoon: a study of the effect of shelter from wave action. Trans R Soc S Afr 35:475-547
De Grave S, Whitaker A (1999) Benthic community re-adjustment following dredging of a muddy-maerl matrix. Mar Pollut Bull 38:102-108

Ellis J, Cummings V, Hewitt J, Thrush S, Norkko A (2002) Determining effects of suspended sediment on condition of a suspension feeding bivalve (Atrina zelanica): results from a survey, a laboratory experiment and a field transplant experiment. J Exp Mar Biol Ecol 267:147-174

Estes JA, Duggins DO (1995) Sea otters and kelp forests in Alaska: generality and variation in a community ecological paradigm. Ecol Monogr 65:75-100

Estes JA, Smith NS, Palmisano JF (1978) Sea otter predation and community organisation in the Western Aleutian Islands, Alaska. Ecology 59:822-833

Estes JA, Tinker MT, Williams TM, Doak DF (1998) Killer whale predation on sea otters linking oceanic and nearshore ecosystems. Science 282:473-476

Flach E, Tamaki A (2001) Competitive bioturbators on intertidal sand flats in the European Wadden Sea and Ariake Sound in Japan. In: Reise K (ed) Ecological comparisons of sedimentary shores. Ecological studies, Vol 151. SpringerVerlag, Berlin, p 149-171

Graham MA (1994) Association of juveniles of four fish species with sandbanks in Durban Bay, KwaZulu Natal. MSc thesis, University of KwaZulu, Durban

Kaiser MJ, Ramsay K, Richardson CA, Spence FE, Brand AR (2000) Chronic fishing disturbance has changed shelf sea benthic community structure. J Anim Ecol 69:494-503

Kaiser MJ, Collie JS, Hall SJ, Jennings S, Poiner IR (2002) Modification of marine habitats by trawling activities: prognosis and solutions. Fish Fish 3:114-136

McInnes AM, Allan DG, Malan G (2005) Key sites for the conservation of waterbirds (Aves) in Durban Bay, South Africa. Durban Mus Novitates 30:1-14

Morgans JFC (1956) Notes on the analysis of shallow-water soft substrata. J Anim Ecol 25:367-387

Murphy RC (1985) Factors affecting the distribution of the introduced bivalve, Mercenaria mercenaria, in a California lagoon - the importance of bioturbation. J Mar Res 43: $673-692$

Pillay D (2002) The macrobenthos of the Little Lagoon, Durban Bay. MSc thesis, University of KwaZulu, Durban

> Pillay D, Branch GM, Forbes AT (2007a) Experimental evidence for the effects of the thalassinidean sandprawn Callianassa kraussi on macrobenthic communities. Mar Biol 152:611-618

Pillay D, Branch GM, Forbes AT (2007b) The influence of bioturbation by the sandprawn Callianassa kraussi on feeding and survival of the bivalve Eumarcia paupercula and the gastropod Nassarius kraussianus. J Exp Mar Biol Ecol 344:1-9

Pillay D, Branch GM, Forbes AT (2007c) Effects of Callianassa kraussi on microbial biofilms and recruitment of macrofauna: a novel hypothesis for adult-juvenile interactions. Mar Ecol Prog Ser 347:1-14

Rhoads DC, Young DK (1970) The influence of deposit-feeding organisms on sediment stability and community trophic structure. J Mar Res 28:150-178

$>$ Rowden AA, Jones MB (1993) Critical evaluation of sediment turnover estimates for Callianassidae (Decapoda: Thalassinidea). J Exp Mar Biol Ecol 173:265-272

Siebert T, Branch GM (2005a) Interactions between Zostera capensis, Callianassa kraussi and Upogebia africana: deductions from field surveys in Langebaan Lagoon, South Africa. Afr J Mar Sci 27:345-356

Siebert T, Branch GM (2005b) Interactions between Zostera capensis and Callianassa kraussi: influences on commu- 
nity composition of eelgrass beds and sandflats. Afr J Mar Sci 27:357-373

Siebert T, Branch GM (2007) Ecosystem engineers: interactions between eelgrass Zostera capensis and the sandprawn Callianassa kraussi and their indirect effects on the mudprawn Upogebia africana. J Exp Mar Biol Ecol 340: $11-24$

Suchanek TH (1983) Control of seagrass communities and sediment distribution by Callianassa (Crustacea: Thalassinidea) bioturbation. J Mar Res 41:281-298

Tamaki A (1994) Extinction of the trochid gastropod, Umbonium (Suchium) moniliferum (Lamarck), and associated species on an intertidal sand flat. Res Popul Ecol 36: 225-236

Tomiyama T, Katayama S, Omori M, Honda H (2005) Importance of feeding on regenerable parts of prey for juvenile

Editorial responsibility: Jake Rice,

Ottawa, Ontario, Canada stone flounder Platichthys bicoloratus in estuarine habitats. J Sea Res 53:297-308

Tudhope AW, Scoffin TP (1984) The effects of Callianassa bioturbation on the preservation of carbonate grains in Davies Reef Lagoon, Great Barrier Reef, Australia. J Sediment Petrol 54:1091-1092

> Underwood AJ, Chapman MG, Connell SD (2000) Observation in ecology: you can't make progress on process without understanding the patterns. J Exp Mar Biol Ecol 250: $97-115$

van Nes EH, Amaro T, Scheffer M, Duineveld GCA (2007) Possible mechanisms for a marine benthic regime shift in the North Sea. Mar Ecol Prog Ser 330:39-47

$>$ Zajac RN, Whitlatch RB (1989) Natural and disturbanceinduced demographic variation in an infaunal polychaete, Nephtys incisa. Mar Ecol Prog Ser 57:89-102

Submitted: April 2, 2008; Accepted: June 30, 2008

Proofs received from author(s): October 16, 2008 